\title{
ANALISIS AWAN HUJAN PADA SAAT BANJIR DKI DENGAN C-BAND RADAR
}

\author{
Findy Renggono
}

\begin{abstract}
Intisari
Banjir besar kembali melanda ibukota Jakarta pada tanggal 17 Januari 2013. Hujan yang deras sejak tanggal 12 Januari 2013 di wilayah Jabodetabek menyebabkan banjir kembali melanda wilayah Jakarta. Banyaknya genangan juga menimbulkan kemacetan yang luar biasa yang kemudian menyebabkan lumpuhnya aktifitas ekonomi. Banjir ini disebut-sebut sebagai yang terburuk setelah banjir tahun 2007. BMKG melaporkan bahwa hujan ekstrim terjadi pada tanggal 17 dan 18 Januari, dan hal ini juga terpantau oleh TRMM yang mencatat bahwa hujan terjadi terus-menerus dengan curah hujan yang tinggi sejak tanggal 12. Analisis data radar menunjukkan bahwa pada tanggal 17, hampir seluruh wilayah Jakarta ditutupi oleh awan hujan yang tebal. Awan-awan hujan yang muncul mencapai ketinggian lebih dari $7 \mathrm{~km}$ dan masuk ke Jakarta dari arah Barat Laut. Pada tanggal 17, hampir seluruh awan hujan yang muncul mempunyai ketebalan lebih dari $7 \mathrm{~km}$.
\end{abstract}

\begin{abstract}
Heavy flood has been hit Jakarta on January 17 , 2013. Heavy rains from January 12, 2013 in the Greater Jakarta area causing floods, which is said as the worst since 2007. $B M K G$ reported that extreme rainfall occurred on 17 and 18 January, and it is also observed by TRMM which noted that rain occurs continuously with high rainfall since the Jan 12th. Radar data analysis showed that on the 17th, almost the entire area of Jakarta covered by thick towering precipitation clouds. These clouds appeared more than $7 \mathrm{~km}$ height and move Westward - Northwestward. On the 17th, almost all the rain clouds that appear to have a thickness of more than $7 \mathrm{~km}$.
\end{abstract}

Kata Kunci : banjir, analisis data radar, awan hujan

\section{Pendahuluan}

Jakarta merupakan ibu kota Indonesia yang selalu bermasalah jika dilanda hujan deras selama lebih dari dua hari berturut-turut. Curah hujan yang tinggi menyebabkan banyak genangan di jalan-jalan ibukota sehingga mengakibatkan kemacetan yang luar biasa. Hujan yang ekstrim dapat menyebabkan sungai meluap dan akhirnya menggenangi perumahan di sekitar aliran sungai. Beberapa kejadian hujan yang menyebabkan banjir besar di Jakarta adalah hujan deras pada tahun 2005 dan 2007 yang mengakibatkan jalan-jalan utama di lbukota, tergenang air sehingga menyebabkan aktifitas terhenti. Pada tahun 2013 ini kembali terjadi hujan yang terus-menerus sejak tanggal 12 Januari 2013. Genangan air sudah mulai terjadi di beberapa tempat pada tanggal 15 Januari, namun puncaknya adalah pada tanggal 17 Januari, banjir sudah menggenangi jalanjalan utama di Jakarta. Diduga kejadian banjir ini merupakan yang terburuk setelah kejadian banjir tahun $2007 \quad$ (http://edition.cnn.com/ 2013/01/18/world/asia/indonesia-jakarta-floods).
Pengamatan hujan dengan radar merupakan metoda yang sudah lama digunakan untuk melengkapi metoda-metoda lain yang selama ini sudah lebih dahulu digunakan, seperti misalnya dengan penakar hujan manual, otomatis, maupun AWS (dan kemudian ada lagi radar hujan dengan satelit TRMM). Namun masing-masing perlatan tersebut mempunyai kelebihan dan kekurangannya. Kekurangan dari penggunaan penakar hujan adalah kesulitan penempatan penakar hujan di lokasi-lokasi yang sulit dijangkau dan untuk pengamatan pada wilayah yang luas, dibutuhkan banyak penakar hujan. Sedangkan penggunaan satelit juga terkendala oleh biaya yang mahal dan resolusi waktu yang terlalu besar. Sebagai contoh, hasil analisis data TRMM untuk suatu wilayah mempunyai kerapatan waktu sebesar satu jam, sedangkan untuk mengamati kejadian hujan, terutama hujan konvektif biasanya mempunyai siklus hidup hanya 30 menit sebelum berubah menjadi stratiform atau mati.

Beberapa penelitian awan hujan di Indonesia telah banyak dilakukan, misalnya Mori 
et.al. (2004) yang mengamati pergerakan awan antara laut dan daratan dengan TRMM dan radiosonde, Sakurai et.al (2005) yang juga meneliti siklus pergerakan awan di Sumatera. Sedangkan Hamada (2008) melakukan penelitian tentang karakteristik hujan di pantai dan dan darat. Penelitian dengan radar juga telah dilakukan sejak tahun 1990-an. Renggono. F. et.al. (2001) menggunakan BLR untuk melakukan klasifikasi awan hujan di Jakarta, Kozu. T., et.al. (2005) melakukan analisis distribusi butir hujan dengan menggunakan EAR di Kototabang, Sumatera Barat, sedangkan pengamatan awan hujan dengan radar untuk melihat sistem konfeksi di sepanjang garis pantai Barat Sumatera dilakukan oleh Mori. S., et.al. (2011) dan juga Shibagaki et.al. (2006).

CDR yang mempunyai kerapatan waktu sekitar 6 menit dapat memantau hujan konvektif dan stratiform secara baik. Jangkauan pengamatannya yang sampai $100 \mathrm{~km}$ mampu mengamati kondisi awan hujan di wilayah Jabodetabek dan sekitarnya, termasuk awanawan hujan yang akan masuk ke wilayah DKI. Dengan kemampuan ini, CDR dapat digunakan untuk peringatan dini banjir DKI maupun sebagai analisis kondisi awan hujan yang muncul yang menyebabkan banjir di Jakarta. Dengan melakukan analisis awan hujan, diharapkan prediksi untuk bencana banjir lebih akurat dan strategi penanganannya juga dapat lebih tepat. Selain itu, kajian ini juga sangat diperlukan oleh UPT Hujan Buatan untukmengetahui jenis awan dan pola penyebarannya sehingga dapat ditentukan metoda penyemaian awan yang tepat agar lebih efektif dan efisien.

Tujuan dari tulisan ini adalah untuk melihat karakteristik awan hujan yang masuk ke wilayah DKI, dan mengetahui jenis awan hujan yang dapat menimbulkan banjir di Jabodetabek.

\section{Data dan Metoda}

Pengamatan awan dilakukan dengan menggunakan C-band Doppler Radar (CDR) yang merupakan kerjasama JAMSTEC dengan BPPT, yang terletak di Serpong (106.66E, 6.36S) (Gambar 1). Radar yang menggunakan antena parabola dengan diameter $3 \mathrm{~m}$ ini beroperasi pada frekuensi 5.32 Ghz (C-band), memiliki daya pancar sebesar $200 \mathrm{~kW}$, dan mampu memantau keberadaan hujan sampai sekitar 100km (Yamanaka et.al.,2008). Dengan radar ini dapat diketahui lokasi, ukuran, pergerakan dan kondisi awan hujan yang muncul di sekitar wilayah Jakarta. Spesifikasi detil dapat dilihat pada Tabel 1.

Antena radar berputar secara horizontal dan berubah sudut elevasi secara teratur untuk mendapatkan data spasial dengan lengkap dengan memancarkan gelombang elektromagnetik dan menangkap kembali sinyal yang terpantul oleh butir- butir air yang ada di awan. Parameter yang diperoleh adalah reflektifitas, lebar spektrum dan Doppler shift untuk tiap level ketinggian. Gambar 2 menunjukkan potongan tegak lurus dari reflektifitas radar pada tanggal 17 Januari 2013 jam 02.11 UTC (09.11 WIB) di 6.0S pada saat kejadian hujan. Terlihat pada gambar ini reflektifitas radar yang tinggi pada 106.40 106.70E. Keberadaan reflektifitas radar yang tinggi menunjukkan banyaknya kadungan butir air atau besarnya ukuran butir air di awan.

Tabel 1. Spesifikasi CDR Serpong

\begin{tabular}{|c|l|}
\hline Location & $\begin{array}{l}\text { Serpong/Jakarta } \\
6.4 \mathrm{~S}, 106.7 \mathrm{E}, 50 \mathrm{~m} \mathrm{MSL}\end{array}$ \\
\hline Operational frequency & $5.32 \mathrm{GHz}$ \\
\hline Antenna: & \\
\hline Shape & parabolic \\
\hline Size & $3 \mathrm{~m}$ diameter \\
\hline Gain & $40 \mathrm{dBi}$ \\
\hline Beam width & $1.6 \mathrm{deg}$ \\
\hline Elevation angle & -2 to +90 deg \\
\hline Polarization & Horizontal \\
\hline Rotation rate (max) & $24 \mathrm{deg} / \mathrm{s}$ (horizontal), \\
& $12 \mathrm{deg} / \mathrm{s}$ (vertical) \\
\hline Transmitter: & \\
\hline Peak power & $200 \mathrm{~kW}$ \\
\hline Average power & $400 \mathrm{~W}$ \\
\hline Pulse length & $1.0 \mu \mathrm{s}$ \\
\hline Pulse repetition frequency & $2000 \mathrm{~Hz}$ \\
\hline Receiver: & \\
\hline Minimum detectable level & $-110 \mathrm{dBm}$ \\
\hline Sampling range (max) & $100 \mathrm{~km}$ \\
\hline & \\
\hline
\end{tabular}

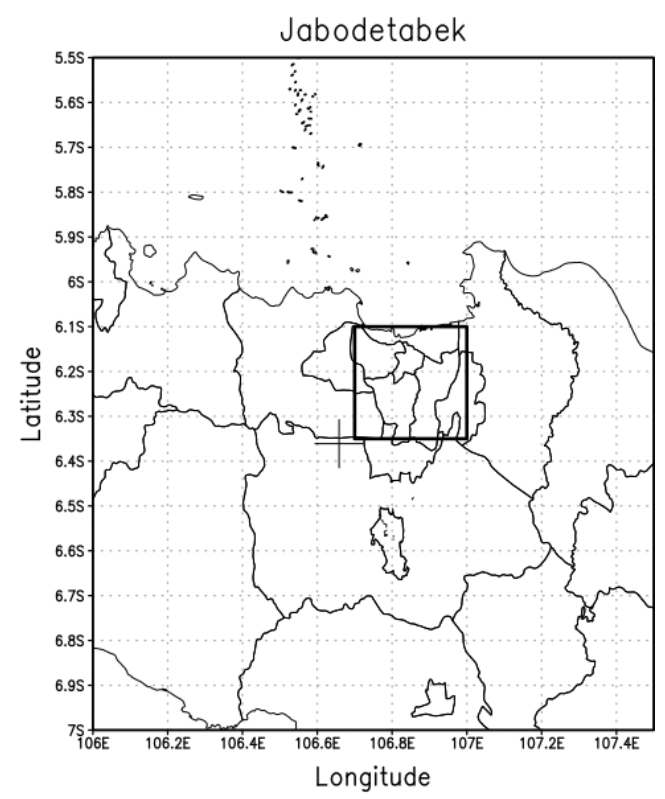

Gambar 1. Daerah pengamatan radar. Tanda plus (+) merupakan lokasi radar

William et. al. (1979) menyebutkan bahwa reflektifitas tinggi yang menjulang dari bawah sampai ke atas merupakan awan hujan 
konvektif, yang berkorelasi dengan curah hujan yang tinggi (lebih dari $10 \mathrm{~mm} / \mathrm{h}$ ). Sedangkan berkorelasi dengan curah hujan yang rendah $(10-100 \mathrm{~mm} / \mathrm{h})$. Pada Gambar 2 terlihat adanya awan hujan konvektif yang muncul di 106.40E-106.45E, dan awan stratiform di 106.50E-106.70E. awan akan dibagi menjadi awan hujan konvektif dan stratiform dengan persyaratan nilai batas untuk reflektifitas adalah 20 dBZ. Renggono et. al. (2001) menggunakan nilai ambang $18 \mathrm{dBz}$ untuk mendeteksi adanya hujan di permukaan sebesar $1.0 \mathrm{~mm} / \mathrm{jam}$, namun dalam tulisan ini digunakan nilai yang lebih reflektifitas yang memanjang secara horizontal merupakan awan hujan stratiform, yang besar karena yang dianalisis adalah hujan dengan curah hujan lebih tinggi dari $1.0 \mathrm{~mm} / \mathrm{jam}$. Jika reflektifitas di atas $20 \mathrm{dBz}$ antara ketinggian 1-10km terdeteksi muncul lebih dari $7 \mathrm{~km}$ maka akan digolongkan sebagai awan jenis konvektif, sedangkan jika hanya muncul di ketinggian 4$5 \mathrm{~km}$ maka akan digolongkan sebagai awan stratiform.

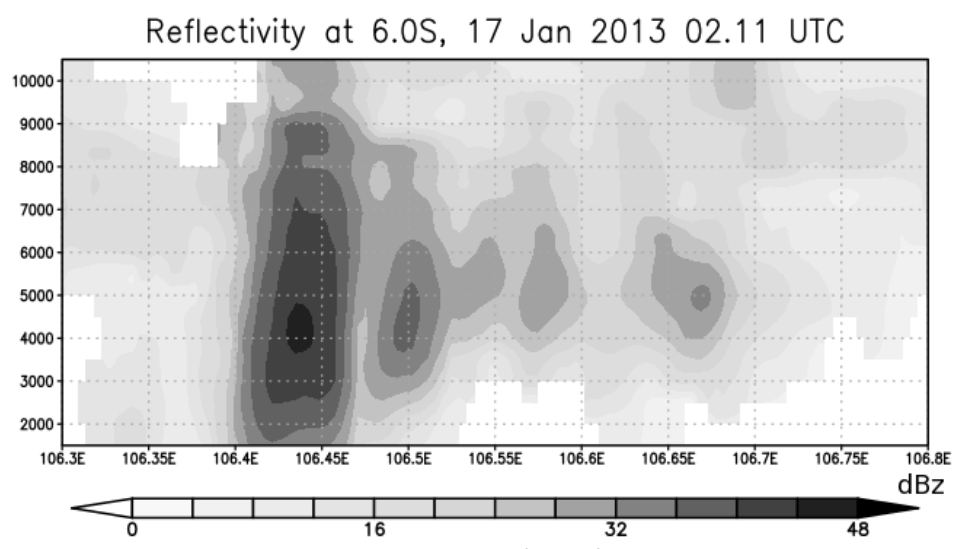

Gambar 2. Potongan tegak lurus reflektifitas radar tgl 17 Jan 2013

Data CDR yang digunakan pada tulisan ini adalah data tanggal 16-18 Januari 2013. Masing-masing hari tidak penuh 24 jam mendapatkan data karena adanya masalah teknis, terutama karena listrik yang mati jika terjadi hujan deras disertai kilat di sekitar lokasi radar. Ketersediaan data dapat dilihat pada kolom yang diarsir warna gelap pada Tabel 2, sedangkan yang berwarna putih tidak ada data.

\subsection{Kondisi cuaca pada tangal $16-18$ Januari 2013}

Hasil pengukuran curah hujan bulan Januari 2013 untuk wilayah DKI dengan TRMM ditunjukkan pada Gambar 3. Gambar ini adalah rata-rata hujan jam-jaman untuk wilayah 6.35S6.10S dan 106.70E-107.00E (lihat gambar 1). Pada gambar ini telihat bahwa hujan deras mulai tampak pada tanggal 12, dan puncaknya adalah tanggal 18. Curah hujan BMKG. tertinggi adalah sebesar $14 \mathrm{~mm} / \mathrm{jam}$ yang terjadi pada tanggal 18 pukul 03 WIB. Setelah tanggal 18, curah hujan terlihat tidak terlalu tinggi. Hasil ini juga konsisten dengan hasil pengukuran langsung oleh penakar hujan di permukaan yang dilakukan oleh BMKG.

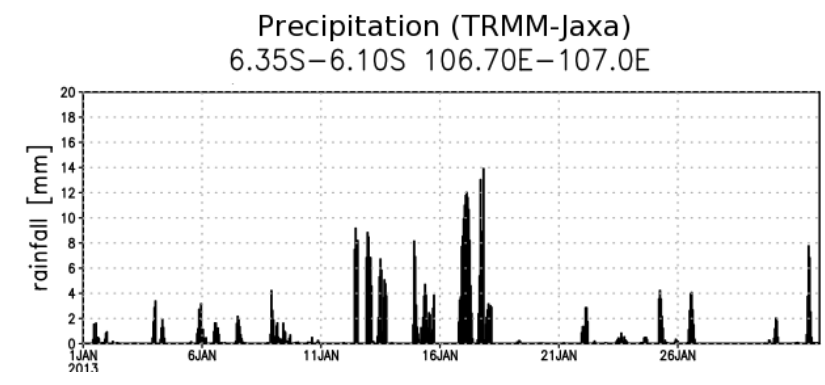

Gambar 3. Curah hujan bulan Januari berdasarkan pengukuran TRMM

Tabel 2. Ketersediaan data Radar

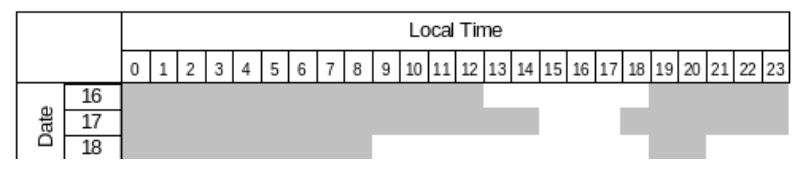


Dalam laporan BMKG untuk kondisi pada bulan Januari 2013 disebutkan bahwa curah hujan pada bulan tersebut mempunyai sifat di atas normal dengan total curah hujan bulanan sangat tinggi (>500 mm). Hujan ekstrim pada bulan Januari yang terjadi di Jakarta terpantau pada penakar BMKG pada tanggal 16, 17 dan 18, yang masing-masing maksimumnya adalah 125mm (Angke Hulu), 135mm (Cengkareng), dan 222mm (Pulo Gadung) (Buletin BMKG Januari 2013). Grafik curah hujan dari 13 penakar di DKI Jakarta tanggal 1518 Januari 2013 dapat dilihat pada Gambar 4. Pada gambar ini terlihat bahwa di beberapa penakar, curah hujan pada tanggal 16 sudah mencapai lebih dari 100mm (katulampa dan Angke Hulu). Sedangkan pada tanggal 17, walaupun hanya di Cengkareng yang curah hujannya lebih dari $100 \mathrm{~mm}$ namun hampir seluruh penakar mencatat curah hujan yang lebih dari 50mm. Puncaknya adalah pada tanggal 18, penakar hujan di Istana dan Pulo Gadung mencatat curah hujan lebih dari 200mm, sedangkan di Karet, Tomang Barat dan Kemayoran lebih dari 150mm, Pakubuwono, Tanjung Priok, dan Cengkareng lebih dari $100 \mathrm{~mm}$ dan lainnya juga di atas $50 \mathrm{~mm}$. Jika dirata-rata, curah hujan dari ke-13 penakar di DKI untuk tanggal 15, 16, 17, dan 18 adalah masing-masing 63.6, 45.0, 60.8, 127.1mm. Angin di sekitar Jabodetabek selama bulan Januari 2013 didominasi oleh angin Baratan, terutama untuk ketinggian dibawah $800 \mathrm{hPa}$. Dari data NCEP untuk lokasi 5.0S, 105.0E terlihat bahwa pada awal bulan Januari angin bergerak dari Barat menuju Timur, namun mulai tanggal 12 arah angin sedikit bergeser dari arah Barat Laut. Hal ini disebabkan adanya pusat tekanan rendah di Laut China, dan menguatnya siklon tropis "Narelle" di Selatan Jawa. Gambar 5 menunjukkan arah dan kecepatan angin pada ketinggian $1000-200 \mathrm{hPa}$ selama bulan Januari 2013.

\subsection{Pengamatan dengan Radar}

Pengamatan reflektifitas radar pada tanggal 16-18 Januari 2013 untuk wilayah 6.35S-6.10S dan 106.70E-107.00E menunjukan bahwa reflektifitas radar menguat pada saat ada hujan (gambar 6). Gambar ini merupakan grafik waktu-ketinggian dari reflektifitas radar. Garis hitam di atas sumbu-x menunjukkan bahwa pada saat tersebut tidak ada pengukuran karena radar sedang mati. Pada tanggal 17 pukul 0209, pukul 21, dan lewat tengah malam tanggal 18, terlihat reflektifitas yang tinggi (di atas $30 \mathrm{dBz}$ ) sampai ketinggian $10 \mathrm{~km}$. Hal ini konsisten dengan data TRMM (gambar 3), dan data BMKG yang menunjukkan curah hujan tinggi tanggal 17-18 Januari (Gambar 4).

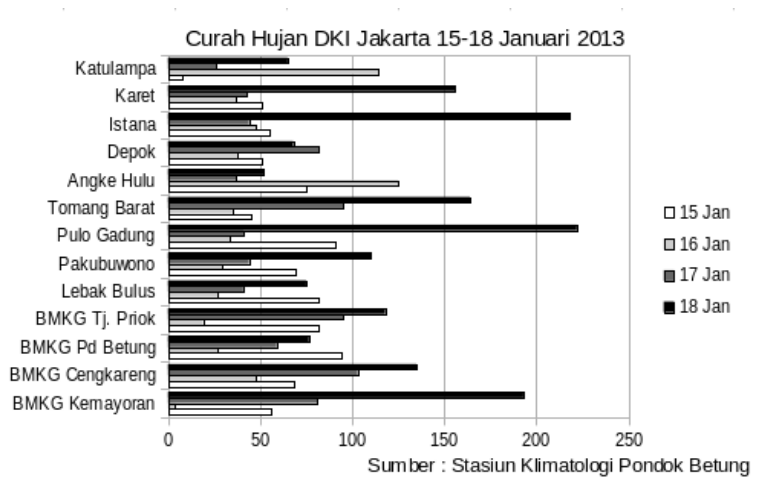

Gambar 4. Curah Hujan permukaan di DKI, hasil pengukuran BMKG.

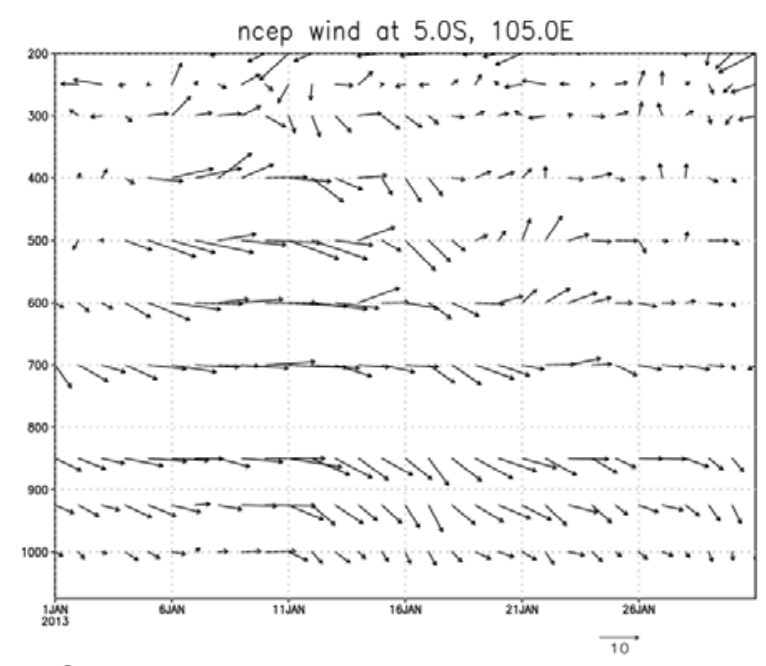

Gambar 5. Arah dan kecepatan angin bulan Januari 2013.

Gambar 7 merupakan gambar reflektifitas radar dan data hujan TRMM untuk tanggal 17 Januari. Gambar kiri adalah diagram longitude-waktu rata-rata reflektifitas radar (latitude 6.35S-6.10S) pada ketinggian 2km, gambar tengah merupakan irisan tegak lurus untuk wilayah yang dibatasi dengan kotak pada gambar sebelah kiri, dan gambar paling kanan merupakan curah hujan jam-jaman yang diukur oleh TRMM. Dari diagram kiri terlihat bahwa awan hujan di wilayah DKI (ditandai dengan kotak dengan garis hitam) mempunyai reflektifitas yang tinggi (> $18 \mathrm{dBz}$ ) pada pukul 313 WIB dan pukul 23 sampai tengah malam (pukul 15-17 tidak ada data). Awan-awan tersebut terlihat bergerak dari Barat ke Timur. Beberapa awan hujan tampak tumbuh di luar wilayah DKI dan masuk menjadi hujan (pukul 3, dan 5), dan ada juga yang tumbuh di dalam wilayah DKI (pukul 8). Dari irisan tegak lurusnya (gambar tengah) terlihat bahwa awan-awan tersebut tumbuh menjulang sampai ketinggian 
lebih dari $16 \mathrm{~km}$. Pada gambar ini juga terlihat dengan jelas bahwa pada pukul 3-5 pagi awan dengan relektifitas lebih dari $25 \mathrm{dBz}$ menjulang dari 2-8km, sedangkan pada pukul 912 siang reflektifitas yang kuat hanya terlihat di ketinggian 5-8km. Pukul 8-9 terlihat awan dengan reflektifitas tinggi, namun hanya sampai ketinggian $5 \mathrm{~km}$. Pada gambar kanan dapat dilihat curah hujan berdasarkan pengukuran dengan satelit TRMM. Nilai curah hujan merupakan rata-rata dari 9 titik yang berada dalam wilayah pengamatan yang sesuai dengan radar. Dari gambar ini terlihat bahwa hujan sudah mulai terjadi sejak pukul 2 pagi dan intensitasnya makin meningkat sampai puncaknya terpatau pada pukul 9 pagi, yang kemudian menurun. Pada malam hari, hujan kembali turun dengan intensitas yang tinggi, yaitu lebih dari $12 \mathrm{~mm} / \mathrm{jam}$. Hujan hasil pantauan TRMM ini sesuai dengan pengamatan radar, seperti misalnya hujan pada pukul 8-9 pagi, di radar juga terlihat awan hujan dengan reflektifitas tinggi yang menjulang sampai ketinggian $6 \mathrm{~km}$. Akan tetapi karena gambar tengah merupakan rata-rata reflektifitas dalam suatu wilayah, maka pada gambar ini masih kurang bisa menjelaskan kenapa hujan pukul 5 pagi, walaupun reflektifitasnya kuat sampai ketinggian lebih dari $5 \mathrm{~km}$ namun curah hujannya tidak setinggi pukul 9 pagi.

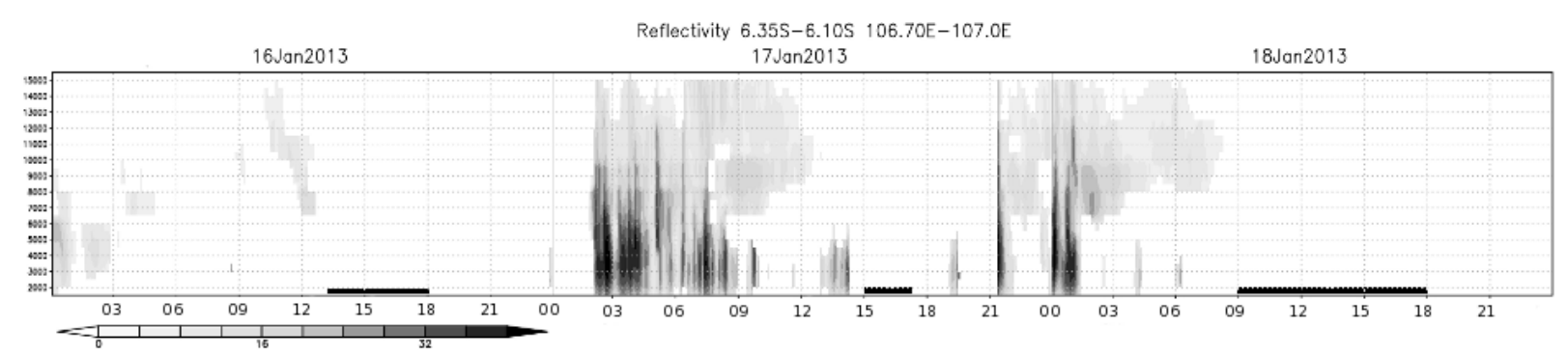

Gambar 6. Potongan tegak lurus waktu-ketinggian dari rata-rata reflektifitas radar tanggal 16-18 Januari untuk wilayah 6.35S-6.10S dan 106.70E-107.00E

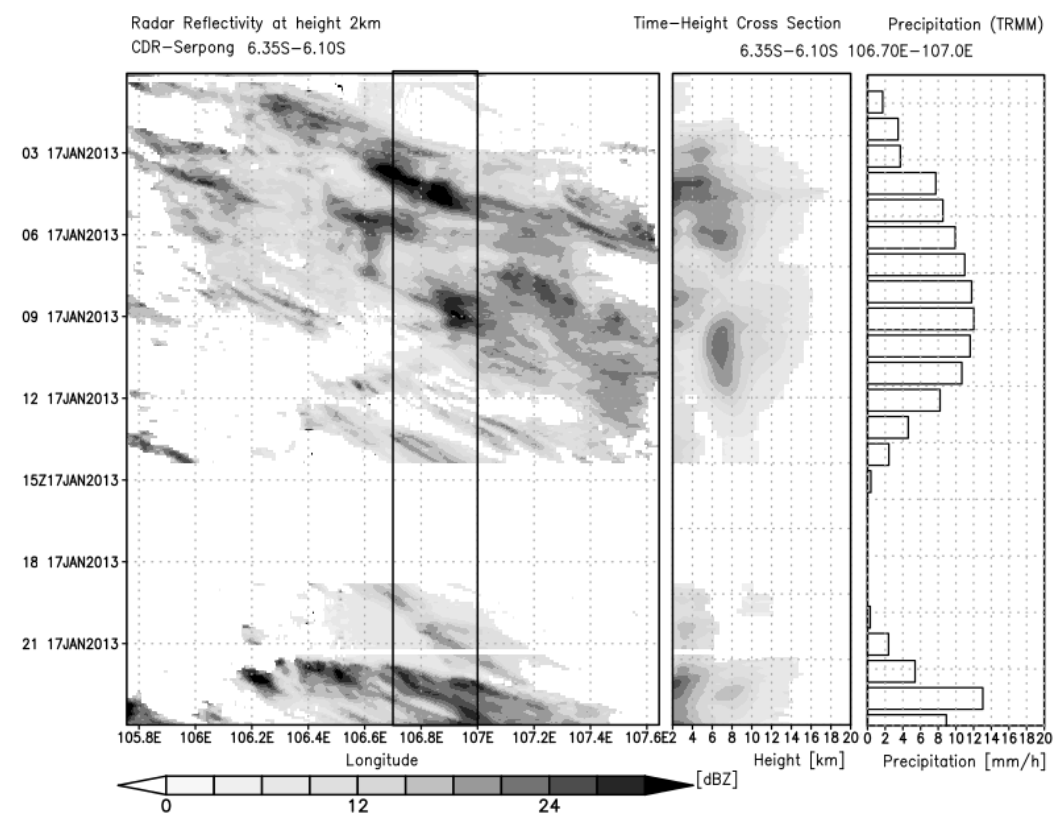

Gambar 7. Reflektifitas radar pada 6.35S-6.10S dan ketinggian 2km (kiri), sama seperti gambar 6 tapi untuk tanggal 17 Jan (tengah), dan curah hujan jam-jaman dari TRMM (kanan)

Dengan menggunakan metoda batas minimal reflektifitas dan ketebalannya, ditentukan awan-awan konvektif dan stratiform untuk mengetahui kemunculan awan pada saat terjadi banjir. Gambar 8 adalah hasil pengamatan radar pada tanggal 17 Januari 2013 pukul 01.35 - 04.23 setiap sekitar 24 menit. Posisi radar tampak di pusat lingkaran (tanda plus (+)), dan awan-awan yang tingginya lebih dari $7 \mathrm{~km}$ (konvektif) ditunjukkan dengan arsir warna gelap, sedangkan awan-awan stratiform (yang menyebar secara horizontal) ditunjukkan dengan arsir terang. Tampak pada gambar ini bahwa awan-awan yang telihat di seputaran dan di dalam wilayah DKI didominasi oleh awanawan konvektif dengan ketebalan minimal $7 \mathrm{~km}$, 
sedangkan awan-awan stratiform tidak terlalu banyak terlihat.

Sekumpulan awan-awan hujan yang besar tampak muncul di atas Banten pada pukul 00.29 dan bergerak masuk menuju Jakarta. Namun di perbatasan terlihat awan-awan tersebut terpecah, dan sebagian lagi bergabung dengan awan-awan yang datang dari Barat Laut. Awan-awan yang muncul di Utara Tangerang bergerak ke arah Tenggara, semakin membesar di pantai utara Jakarta, yang kemudia menjadi hujan di wilayah Jakarta Utara dan Jakarta Pusat. Garis tegas menunjukkan pergerakan awan-awan ini, yang masuk dan kemudian menjadi hujan di Jakarta. Kondisi ini juga sesuai dengan analisis angin dari NCEP yang menyebutkan pergerakan masa udara di jakarta dari Barat-Barat Laut.

Sebaran awan konvektif selama tanggal 17 Jan dapat dilihat pada gambar 9. Kontur pada gambar ini menunjukkan jumlah kemunculan awan yang tingginya lebih dari $7 \mathrm{~km}$. Semakin gelap warnanya, semakin banyak awan tersebut muncul. Pada gambar ini terlihat bahwa awanawan tersebut banyak muncul di Jakarta Utara, Jakarta Pusat, Jakarta Timur dan Bekasi. Dalam 21 jam pengamatan, jumlah kemunculan awanawan tersebut lebih dari 20 kali kemunculan (lebih dari 2 jam).

Sebenarnya ambang batas $7 \mathrm{~km}$ untuk awan konvektif cukup tinggi, karena biasanya awan yang muncul dengan ketinggian $5 \mathrm{~km}$ saja sudah menghasilkan hujan yang cukup deras. Jika batas ambang untuk ketinggian awan konvektif diturunkan menjadi $5 \mathrm{~km}$, kemunculan awan konvektif di wilayah Jakarta bertambah menjadi sekitar lebih dari 4 jam. Hujan dari awan konvektif dengan durasi seperti inilah yang akhirnya menimbulkan banyak genangan di ibu kota.

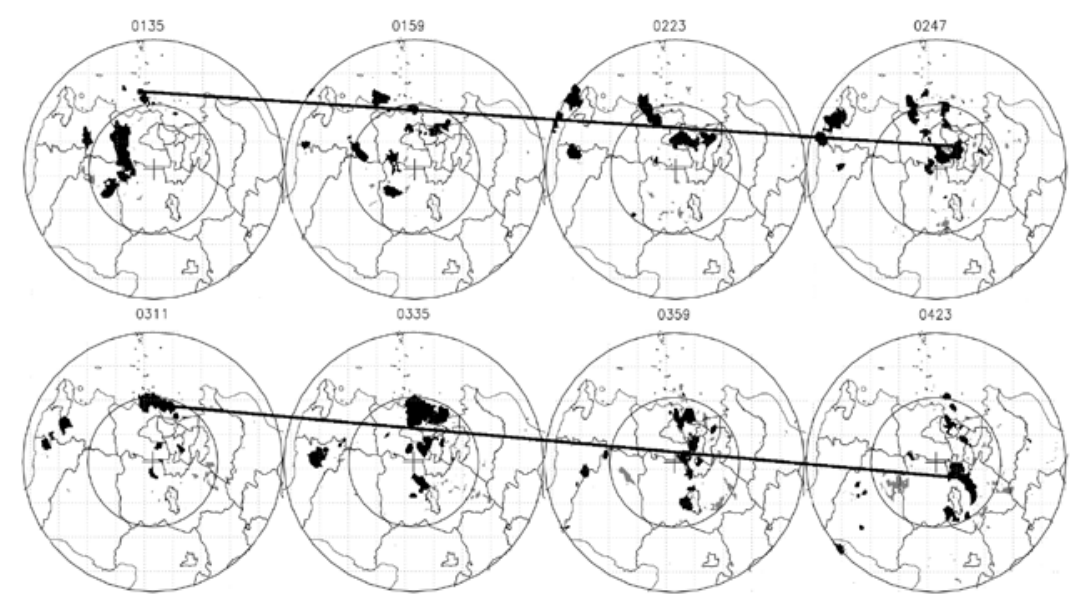

Gambar 8. Pengamatan ketinggian awan dengan radar tanggal 17 Jan 2013 pukul 0029-0359.

Warna arsir gelap merupakan awan yang tingginya lebih dari $7 \mathrm{~km}$, sedangkan arsir terang merupakan sratiform.

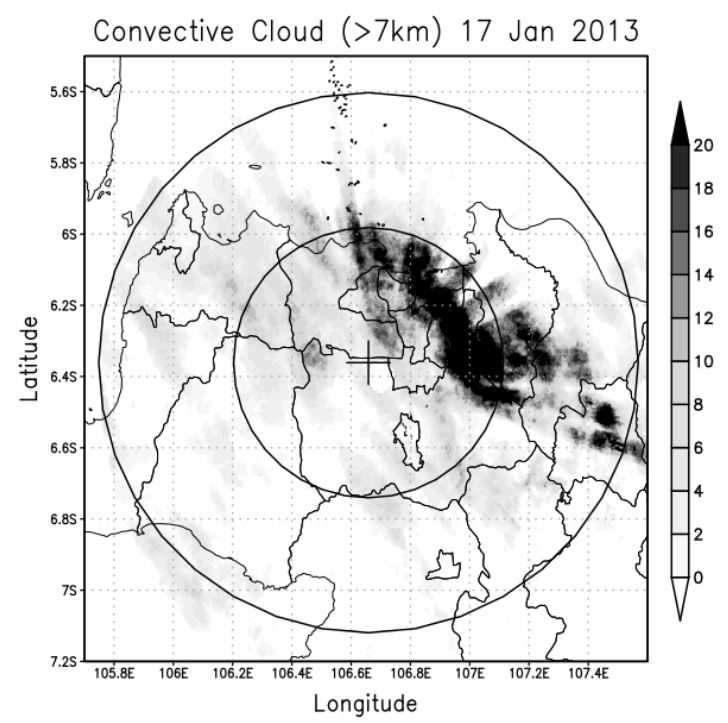

Gambar 9. Jumlah kemunculan awan hujan dengan ketinggian lebih dari $7 \mathrm{~km}$ 


\section{Kesimpulan}

Banjir yang melanda Jakarta bulan Januari 2013 disebabkan oleh hujan yang turun terus-menerus sejak tanggal 12 Januari. Hujan dengan kategori hujan ekstrim terukur oleh BMKG pada beberapa penakarnya yang terpasang di wilayah Jakarta pada tanggal 17 dan 18. Data TRMM menunjukkan hujan yang terus-menerus terjadi pada tanggal 17 pagi hingga siang dan menjelang tengah malam hingga pagi keesokan harinya. Pergerakan udara pada tanggal 12-18 Januari terlihat dari arah Barat Laut, sehingga awan-awan yang masuk ke DKI banyak berasal dari pantai utara Jakarta.

Radar C-band di Serpong berhasil merekam hujan deras pada beberapa hari sebelum sampai sesudah banjir DKI. Analisis data Radar mendukung hasil pengukuran dengan penakar maupun TRMM, yaitu awanawan hujan penghasil curah hujan yang tinggi, yaitu awan-awan konvektif, muncul hampir di sebagian besar wilayah DKI. Awan-awan kovektif ini didefinisikan sebagai awan yang mempunyai ketebalannya lebih dari $7 \mathrm{~km}$ dan mempunyai reflektifitas diatas $20 \mathrm{dBz}$. Awan hujan tersebut pada tanggal 17 Jan banyak terlihat di sebagian besar wilayah DKI dan Bekasi dengan durasi waktu yang cukup lama, yang akhirnya menimbulkan curah hujan yang tinggi.

\section{Ucapan Terima kasih}

Pengamatan dengan C-band Doppler Radar merupakan kerjasama antara JAMSTEC, Jepang dengan TISDA, BPPT. Terima kasih buat Winarno dan Ardhi dari TISDA yang telah membantu membereskan data CDR. Penelitian ini mendapat dukungan penuh dari UPT Hujan Buatan, BPPT.

\section{Daftar Pustaka}

Buletin BMKG Propinsi Banten dan DKI Jakarta, Stasiun Klimatologi Pondok Betung Tangerang, p30, Pebruari 2013.

Hamada, J.-I., M. D. Yamanaka, S. Mori, Y. I. Tauhid and T. Sribimawati, 2008: Differences of rainfall characteristics between coastal and interior areas of central western Sumatera, Indonesia. J. Meteorol. Soc. Japan, 86

Kozu, T., T. Shimomai, Z. Akramin, Marzuki, Y. Shigagaki, and H. Hashiguchi, Intraseasonal variation of raindrop size distribution at Koto Tabang, West Sumatra,
Indonesia, Geophys. Res. Lett., 32, doi:10.1029/3004GL022340, 2005.

Leary.C.A and R.A.Houze. Jr, 1979: Melting and Evaporation of Hydrometeors in Precipitation from the Anvil Clouds of Deep Tropical Convection, J.Atmos.Sci., 36, 669679

Mori, S., J. Hamada, Y.I. Tauhid, M.D Yamanaka, N. Okamoto, F. Murata, N. Sakurai, H. Hashiguchi, and T. Sribimawati, Diurnal land-sea rainfall peak migration over Sumatera Island, Indonesia maritime continent observed by TRMM satellite and intensive rawinsonde soundings, Mon. Weather Rev., 132, 2021-2039, 2004.

Mori, S., Hamada J.-I., N. Sakurai, H. Fudeyasu, M. Kawashima, H. Hashiguchi, F. Syamsudin, A.A. Arbain, R. Sulistyowati, J. Matsumoto, and M.D. Yamanaka, Convective systems developed along the coastline of Sumatera Island, Indonesia, observed with an X-band Doppler radar during the HARIMAU2006 Campaign, J. Meteor. Soc. Japan, 89A, 61-81, 2011.

Renggono. F, H. Hashiguchi, S. Fukao, M. D. Yamanaka, S.-Y. Ogino, N. Okamoto, F. Murata, B. P. Sitorus, M. Kudsy, M. Kartasasmita, and G. Ibrahim, 2001: Precipitating clouds observed by $1.3-\mathrm{GHz}$ BLR in equatorial Indonesia, Ann. Geoph., 19, 889-897

Sakurai, N., F. Murata, M. D. Yamanaka, S. Mori, J. Hamada, H. Hashiguchi, Y.I. Tauhid, T. Sribimawati, and B. Suhardi, Diurnal cycle of cloud system migration over Sumatera Island, J. Meteor. Soc. Japan, 83, 835-850, 2005.

Shibagaki, Y., T. Shimomai, T. Kozu, S. Mori, Y. Fujiyoshi, H. Hashiguchi, M.K. Yamamoto, S. Fukao, and M.D. Yamanaka, Multi-scale aspects of convective systems associated with an intraseasonal oscillation over the Indonesian maritime continent, Mon. Wea. Rev., 134, 1682-1696, 2006.

Yamanaka, M. D., S. Mori, Wu P.-M., Hamada J.-I., N. Sakurai, H. Hashiguchi, M. K. Yamamoto, Y. Shibagaki, M. Kawashima, Y. Fujiyoshi, T. Shimomai, T. Manik, Erlansyah, W. Setiawan, B. Tejasukmana, F. Syamsudin, Y. S. Djajadihardia, and J. T. Anggadiredja, 2008: HARIMAU radarprofiler network over Indonesian maritime continent: A GEOSS early achievement for hydrological cycle and disaster prevention.J. Disaster Res., 3, 78-88. 
